\title{
DETECTION OF DIVAŠKA JAMA CORRIDORS BEHIND (TO THE SW) TRHLOVCA CAVE USING LOW FREQUENCY HIGH POWER GROUND PENETRATING RADAR
}

\section{DOLOČITEV ROVOV DIVAŠKE JAME V JZ SMERI ZA TRHLOVCO Z UPORABO ZELO MOČNEGA NIZKOFREKVENČNEGA GEORADARJA}

\author{
Pavel KALENDA ${ }^{1, *}$, Rudolf TENGLER ${ }^{2}$, Stanka ŠEBELA ${ }^{3}$, \\ Matej BLATNIK ${ }^{3} \&$ Andrej GOSAR ${ }^{4}$
}

\begin{abstract}
UDC 551.442:621.396.96(497.472)

Pavel Kalenda, Rudolf Tengler, Stanka Šebela, Matej Blatnik \& Andrej Gosar: Detection of Divaška Jama corridors behind (to the SW) Trhlovca cave using low frequency high power ground penetrating radar

Ground penetrating radar (GPR) named "Roteg" was used to detect known and unknown passages of Divaška Jama and Trhlovca caves in SW Slovenia. "Roteg's" main characteristics are an extraordinary high power output (20 MW) and high voltage on antennas (up to $20 \mathrm{kV}$ ), which allows penetration more than ten times deeper than common GPRs. During the measurement we used 3-m long antennas $(50 \mathrm{MHz})$ with a central frequency of $50 \mathrm{MHz}$ and we clearly detected the reflections from the depth of $200 \mathrm{~m}$ after data processing. During field survey 22 profiles were completed with a total length of 4487.97 m. Pretnerjeva and Žibernova Dvorana chambers in Divaška Jama were well visible on radarograms. New big cavities, which were detected below profiles P18, P21 and P22, are almost all at the same level of $350-400 \mathrm{~m}$ a.s.l. There is another group of cavities at a level of $420-450 \mathrm{~m}$ a.s.l., which corresponds to Trhlovca. Both cave groups are separated by the gap which extends in the vertical direction, and probably presents a tectonic zone, which is as well visible on the radarograms. By the use of "Roteg" at the karst surface we were able to detect known caves, new - unknown caves and tectonic zones up to $200 \mathrm{~m}$ below the surface.
\end{abstract}

Key words: ground penetrating radar, caves, karst, Divaška Jama, Trhlovca, Slovenia.
Izvleček UDK 551.442:621.396.96(497.472) Pavel Kalenda, Rudolf Tengler, Stanka Šebela, Matej Blatnik \& Andrej Gosar: Določitev rovov Divaške jame v JZ smeri za Trhlovco z uporabo zelo močnega nizkofrekvenčnega georadarja

Nizkofrekvenčni georadar (GPR), imenovan »Roteg", smo uporabili pri zaznavi znanih in neznanih rovov Divaške jame in Trhlovce v JZ Sloveniji. "Rotegove« glavne značilnosti so izjemna moč (20 MW) in visoka napetost do $20 \mathrm{kV}$ na antenah, kar omogoča penetracijo, ki je več kot desetkrat globlja, kot jo dosežejo običajni georadarji. Med meritvami smo uporabili 3 $\mathrm{m}$ dolgi anteni $(50 \mathrm{MHz}) \mathrm{s}$ središčno frekvenco $50 \mathrm{MHz}$. Tako smo po obdelavi podatkov jasno zaznali odboje iz globine 200 $\mathrm{m}$. Med terenskimi meritvami smo izmerili 22 profilov s skupno dolžino $4490 \mathrm{~m}$. Pretnerjeva in Žibernova dvorana v Divaški jami sta bili dobro vidni na georadarskih profilih. Nove velike jame, ki smo jih zaznali pod profili P18, P21 in P22, so skoraj vse na istem nivoju, 350-400 m nad morjem. Druga skupina jam na nadmorski višini 420-450 m ustreza Trhlovci. Obe skupini jam sta ločeni $\mathrm{z}$ vrzeljo $\mathrm{v}$ navpični smeri, ki je verjetno tektonska cona in je dobro vidna na georadarskih profilih. Z uporabo »Rotega« na kraškem površju smo določili znane jame, nove neznane jame in tektonske cone do globine $200 \mathrm{~m}$ pod površjem.

Ključne besede: georadar (GPR), jame, kras, Divaška jama, Trhlovca, Slovenija.

\footnotetext{
${ }^{1}$ CoalExp, 73904 Pražmo 129, Czech Republic, e-mail: pkalenda@volny.cz

2 Ing. Rudolf Tengler - RTG, Českobratrská 357, 27601 Mělník, Czech Republic, e-mail: rtg@rtg-tengler.cz

${ }^{3}$ ZRC SAZU Karst Research Institute, Titov trg 2, 6230 Postojna, Slovenia, e-mail: sebela@zrc-sazu.si, mblatnik@zrc-sazu.si

${ }^{4}$ University of Ljubljana, Faculty of Natural Sciences and Engineering and Slovenian Environment Agency, Seismology and Geology Office, Vojkova 1b, 1000 Ljubljana, Slovenia, e-mail: Andrej.Gosar@gov.si

* Corresponding author
}

Received/Prejeto: 08.09.2017 


\section{INTRODUCTION}

The detection of cavities is one of primary goals of GPR method in karst regions (Gosar 2012). Unfortunately, most existing ground penetrating radars (GPR) are unable to detect cavities deeper than $30 \mathrm{~m}$ below the ground, even when low frequencies and large antennas are used (Bláha et al. 1999; Hladík \& Hruška 1999; Chamberlain et al. 2000; Knez \& Slabe 2005; Pavlič \& Praznik 2011; Gosar 2012).

In 2014 a new kind of GPR named "Roteg" was developed (RTG-Tengler 2013). Its main characteristic is an extraordinary high power output (20 MW) and high voltage on antennas (up to $20 \mathrm{kV}$ ). This is more than two orders larger than in the case of usual GPRs. Such big power allows penetrating more than ten times greater depths than common GPRs.

In 2015 - 2017 we tested "Roteg” GPR at several places (in brackets are positively verified penetrating depths): Pytlíková Cave (20 m) (Kalenda et al. 2016), quarry Malá Dohoda (20 m) (Kalenda et al. 2016), below the quarry $\mathrm{Na}$ Bradinách $(20 \mathrm{~m})$ (Kalenda et al. 2016), Holštejnská Cave (40 m) (Kalenda \& Tengler
2016), Spodní Suchdolská Cave (40 m) (Kalenda et al. 2016), Lopač Cave (20 - $60 \mathrm{~m})$ (Tengler et al. 2016), cave No.561A in the quarry Velká Dohoda (40 m with 1-m antennas - $150 \mathrm{MHz}$ ) (Kalenda et al. 2016), cave Amatérská Jeskyně (90 - 110 m) (Tengler et al. 2016), Pekárna Cave $(140 \mathrm{~m})$ (Kalenda et al. 2017a). After such positive results, we tested the most powerful version in Slovenia above cave system Postojnska - Planinska Jama. We clearly detected caves Jama Na Poti (40 m) (Kalenda et al. 2017b), Črna Jama and Pivka Jama (60 - 70 m) (Kalenda et al. 2018), Postojnska Jama (80 - $150 \mathrm{~m})$ and Planinska Jama (180 m) (Kalenda et al. 2018).

Therefore, the detection of Divaška Jama corridors at depths of $30-100 \mathrm{~m}$ should not be a problem for "Roteg" GPR. In this study we first repeated part of the measurements performed by Gosar (2012) above Divaška Jama using $50 \mathrm{MHz}$ antenna as a test. Next we prolonged the measurements behind (to the SW) Trhlovca cave to detect undiscovered parts of Divaška Jama and a possible new cave too.

\section{THE GPR METHOD AND LOW-FREQUENCY HIGH-POWER GPR SYSTEM „ROTEG“}

GPR produces the short electromagnetic pulses, which are transmitted to the ground by transmitting antenna. The second antenna of the GPR measures the travel time and amplitude of the reflected electromagnetic waves, which are reflected on inhomogeneities (from the viewpoint of electrical conductivity). The delay of the receiving signal depends on the depth of inhomogeneity and velocity of electromagnetic signals in the rock. The velocity of EM signal in rock-mass depends on its permittivity $(\varepsilon)$ according to the equation (Allred et al. 2008):

$$
v_{m}=\frac{v_{0}}{\sqrt{\frac{\varepsilon_{m}}{\varepsilon_{0}}}}
$$

where: any material

$\mathrm{v}_{\mathrm{m}}$ - velocity of the wave propagation through

$\mathrm{v}_{0}$ - speed of light in air

$\varepsilon$ - permittivity of the material

$\varepsilon_{0}^{\mathrm{m}}$ - permittivity of free space or vacuum.
In our case we used the velocity for wet limestone $0.12 \mathrm{~m} / \mathrm{ns}$ (Cassidy 2009).

The penetration depth is the crucial factor, which limits the applications of GPRs. For high-frequency GPRs, the relatively small penetration depth (only several meters) is due to high attenuation of the high-frequency signal. The penetration depth for low-frequency GPR (below $100 \mathrm{MHz}$ ) is limited to dozens of meters mostly by mineralized water, which converts the energy to the heat (Smith \& Jol 1995; van der Kruk et al. 1999).

Preliminary test in Moravian Karst (Czech Republic) confirms that in suitable conditions (limestone covered by at least one meter thick soil), the penetration depth is larger than $100 \mathrm{~m}$ and in the case of high thickness of wet soil (several meters), the penetration depth decreased to $\approx 40 \mathrm{~m}$ (Tengler et al. 2016).

The new "Roteg" GPR, compared to the existing GPRs, is characterized by a much higher pulse power (up to $20 \mathrm{MW}$ ), higher voltage of antennas (5-20 $\mathrm{kV}$ ), and in particular by the special design of the pulse generator, which bypasses frequently used semiconductor components MOS and LDMOS, and uses a spark gap instead. This spark gap (discharger) produces Dirac pulses up to 4 ns long by directly discharging capacitors 
(RTG-Tengler 2013). The predominant frequencies are selected from the continuous spectrum by a special antenna, which is tuned to them. The 6-metre long antenna is tuned to the predominant frequency of $25 \mathrm{MHz}$, the 3-metre antenna is tuned to $50 \mathrm{MHz}$, and 1-metre antenna is tuned to $150 \mathrm{MHz}$. Under optimal conditions, when the soil and young sedimentary cover is not thicker than few metres, the reflections of the cave ceiling were clearly detectable using the 6-metre antennas at the depths of around 100 metres under the surface (Tengler et al. 2016).

We used 3-m antennas ( $50 \mathrm{MHz}$ ) and maximal power $(20 \mathrm{MW})$ in the case of measurement above Divaška Jama and behind Trhlovca. We stacked approximately 10 pulses, with the frequency of pulse generation of $120 \mathrm{~Hz}$ at a propagation speed of approx. $3 \mathrm{~km} / \mathrm{h}$, into one sum with the step of $0.1 \mathrm{~m}$. The accuracy of positioning of the measurement point by on-line GPS was approx. $1 \mathrm{~m}$. The length of records is 2,992 ns obtained with 10.801 samples at $0.277 \mathrm{~ns}$. This corresponds to the converted depth of approx. $360 \mathrm{~m}$ at a wave velocity of $12 \mathrm{~cm} / \mathrm{ns}$. The sampling frequency was $3.6 \mathrm{GHz}$. The wave velocity of $12 \mathrm{~cm} / \mathrm{ns}$ is a table value for typical limestone and it was verified by the curvature of hyperbolas on radarograms.

The REFLEXW program (Sandmeier Software) was used for the data processing. The data was processed using the following sequence:

The signal was amplified with depth, the signal was averaged in $\mathrm{x}$ and $\mathrm{y}$ axes using 20 samples (elimination of $\mathrm{HF}$ noise). Frequencies below $5 \mathrm{MHz}$ and above $40 \mathrm{MHz}$ were filtered to highlight large structures only and remove noise. The used 3-m antennas with $50 \mathrm{MHz}$ central frequency are wide-band antennas with wide frequency band between 5 and $500 \mathrm{MHz}$. The received signal therefore must be processed in accordance with the purpose of the measurement.

\section{RESULTS}

\section{TEST MEASUREMENT ABOVE KNOWN PARTS OF DIVAŠKA JAMA}

We started the measurements above known corridors and chambers of Divaška Jama, where common GPR was not successful (Gosar 2012) (Fig. 1).

In Tab. 1 coordinates and lengths of all performed field GPR profiles are presented.

Profile P4_900 started at the main road Divača Lokev, finished after $300 \mathrm{~m}$ at the start of profile P1. The record length was exceptionally set at 15,000 samples (900 m depth). The other profiles (Fig. 1 and 9) were set to the maximum of penetration depth of $360 \mathrm{~m}$, because we were not looking for deeper caves in this area.

Profile P4_900 detected a relatively small cavity at the depth of $30 \mathrm{~m}$ at the beginning of the profile (until the position of $40 \mathrm{~m}$ ) (Fig. 2 - A4). The second important structure is probably a corroded interlayer geological structure (bedding?) with several cavities, which starts at the profile position of $10 \mathrm{~m}$ at the depth of $65 \mathrm{~m}$ and finishes at the position of $120 \mathrm{~m}$ at the depth of $30 \mathrm{~m}$ (B4). One small cavity was created on the same structure at the position of $176 \mathrm{~m}$ at the depth of $17 \mathrm{~m}(\mathrm{C} 4)$. The third important structure is probably part of Divaška Jama at the position of $190-210 \mathrm{~m}$ and the depth of $60 \mathrm{~m}$ accompanied by another cavity $20 \mathrm{~m}$ below it (at the depth of $80 \mathrm{~m}$ ) at the position $210-230 \mathrm{~m}$.

Profile P1 started at the end of profile P4_900 and finished on the forest road. We detected an undiscovered cave at the position between $45-65 \mathrm{~m}$ at the depth of 50 $-65 \mathrm{~m}$ (Fig. 3). It is probably an unknown part of Divaška Jama, which can continue to the north by a deeper corridor below the chamber Pretnerjeva Dvorana.

Profile P2 crossed Divaška Jama and finished at a bush (Fig. 1). The profile of ceiling of the chamber Pretnerjeva Dvorana in Divaška Jama is nicely seen between positions of $33 \mathrm{~m}$ and $64 \mathrm{~m}$ at the depth of $20-25 \mathrm{~m}$ (Fig. 4).

Two strong reflections are visible at the beginning of the cave at the position of $8 \mathrm{~m}$ and the depth of $45 \mathrm{~m}$ and at the end of the profile at the depth of $35 \mathrm{~m}$. Both of them are cavities probably genetically connected with Divaška Jama.

The profile P5, which was planned to be parallel with the Divaška Jama main corridor (Fig. 1), did not show any important cave at the depth between 30 and 70 $\mathrm{m}$ (Fig. 5). The most important structure, which is only seen, is probably corroded interlayer geological structure with several cavities, which starts at the beginning of the profile at the depth of $100 \mathrm{~m}$ and finishes at the position of $50 \mathrm{~m}$ at the depth of $110 \mathrm{~m}$.

Profile P6 started approximately $15 \mathrm{~m}$ east of the known end of Divaška Jama and finished behind Trhlovca.

Three important cavities were detected on this profile at the depth of Divaška Jama - at the position of $12 \mathrm{~m}$ at the depth of $35 \mathrm{~m}$, at the position of $112-120 \mathrm{~m}$ at the 


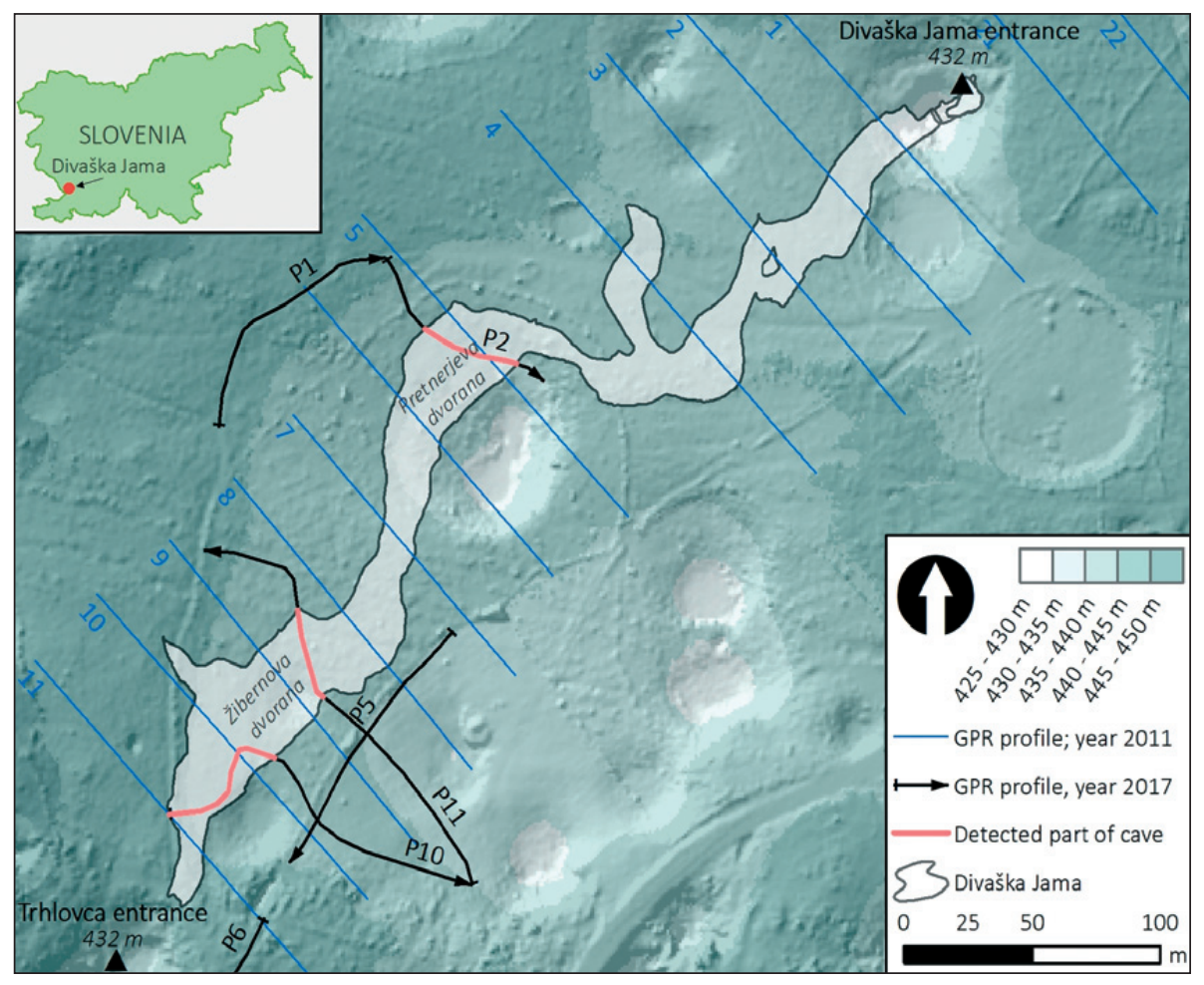

Fig. 1: GPR profiles measured above known part of the cave Divaška Jama. Blue lines - profiles of Gosar (2012), black curves - profiles of "Roteg" GPR 2017. Red - detected ceiling of the cave (Figs. 4, 7 and 8).

\begin{tabular}{|l|c|c|c|c|c|}
\hline & \multicolumn{2}{|c|}{ start } & \multicolumn{2}{c|}{ end } & \\
\hline & lon $\left(^{\circ}\right)$ & lat $\left(^{\circ}\right)$ & lon $\left(^{\circ}\right)$ & lat $\left(^{\circ}\right)$ & length $(\mathrm{m})$ \\
\hline P4_900 & 13.948161 & 45.671864 & 13.947150 & 45.674182 & 301.70 \\
\hline P1 & 13.947155 & 45.674222 & 13.947923 & 45.674775 & 98.42 \\
\hline P2 & 13.947953 & 45.674795 & 13.948723 & 45.674348 & 87.94 \\
\hline (P4) & 13.948326 & 45.674475 & 13.948342 & 45.673533 & 135.19 \\
\hline P5 & 13.948358 & 45.673511 & 13.947561 & 45.672711 & 116.15 \\
\hline P6 & 13.947455 & 45.672598 & 13.946964 & 45.671687 & 120.18 \\
\hline P7 & 13.946989 & 45.671637 & 13.948121 & 45.671841 & 106.38 \\
\hline P9 & 13.948114 & 45.671853 & 13.946941 & 45.672646 & 135.99 \\
\hline P10 & 13.946982 & 45.672929 & 13.948398 & 45.672746 & 144.45 \\
\hline P11 & 13.948408 & 45.672748 & 13.947005 & 45.673838 & 180.22 \\
\hline P12 & 13.948038 & 45.671676 & 13.944765 & 45.672574 & 307.65 \\
\hline P13 & 13.944760 & 45.672594 & 13.943373 & 45.673278 & 143.25 \\
\hline P14 & 13.943311 & 45.673282 & 13.942660 & 45.672965 & 64.77 \\
\hline P15 & 13.942606 & 45.672850 & 13.945195 & 45.671471 & 302.61 \\
\hline P16 & 13.945225 & 45.671464 & 13.948046 & 45.671279 & 256.77 \\
\hline P17 & 13.948078 & 45.671320 & 13.947827 & 45.671527 & 31.73 \\
\hline P18 & 13.946784 & 45.669352 & 13.943633 & 45.670736 & 295.66 \\
\hline P19 & 13.94359 & 45.670746 & 13.939193 & 45.672119 & 407.98 \\
\hline P21 & 13.939089 & 45.672107 & 13.935675 & 45.672882 & 304.22 \\
\hline P22 & 13.935571 & 45.672911 & 13.931988 & 45.672145 & 304.72 \\
\hline P23 & 13.937355 & 45.672918 & 13.937888 & 45.674506 & 268.06 \\
\hline P24 & 13.937879 & 45.674649 & 13.941950 & 45.674406 & 373.93 \\
\hline & & & & & \\
\hline & & & & \\
\hline
\end{tabular}

Tab. 1: Starts, ends and lengths of profiles according to integrated GPS. 

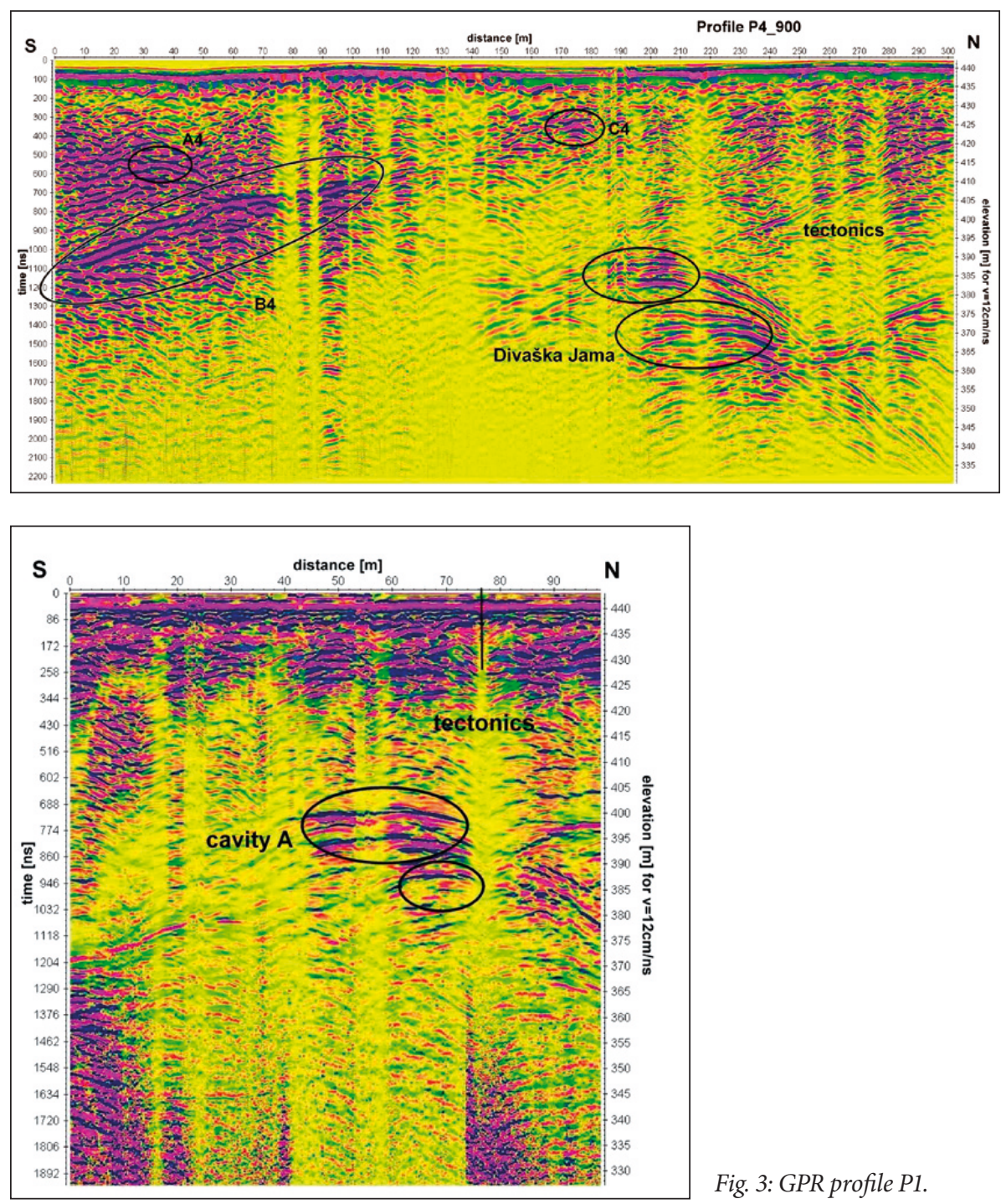

Fig. 2: GPR profile P4_900.
Fig. 3: GPR profile P1.

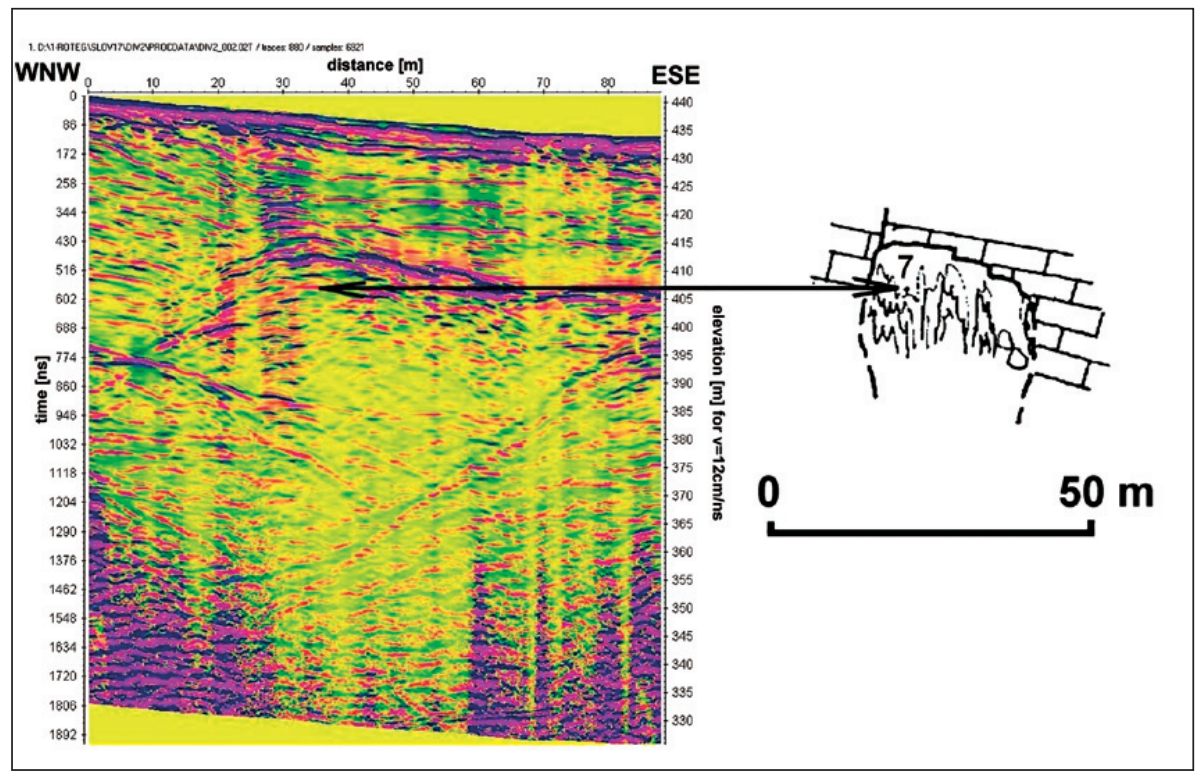

Fig. 4: GPR profile P2 and crosssection of Pretnerjeva Dvorana by Gospodaric (1985). The arrow marks the corresponding trigonometric point. 


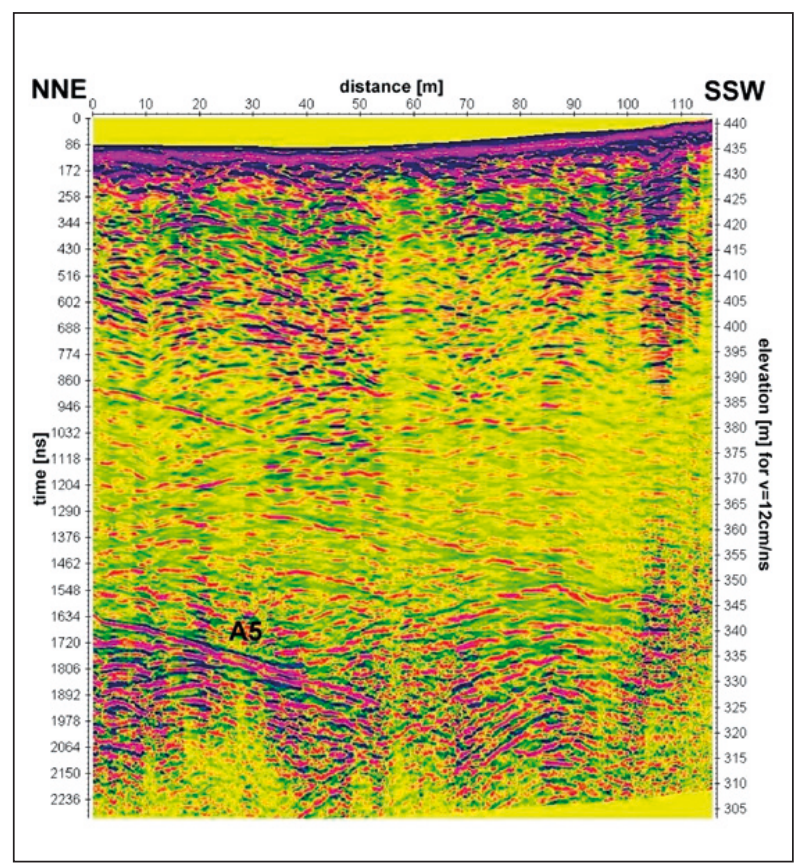

Fig. 5: GPR profile P5.

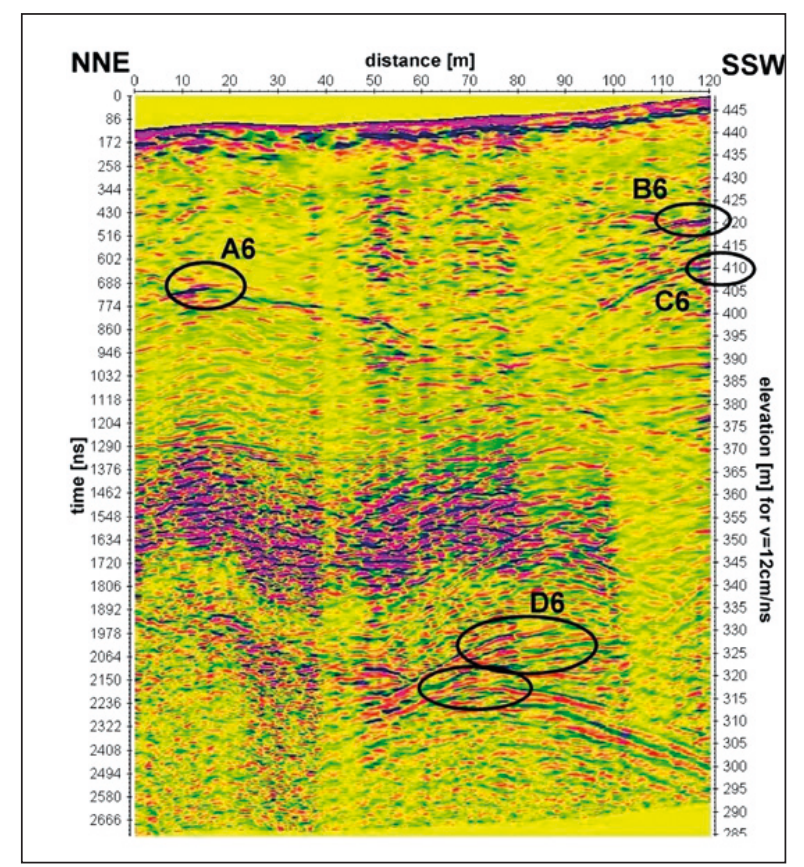

Fig. 6: GPR profile P6.

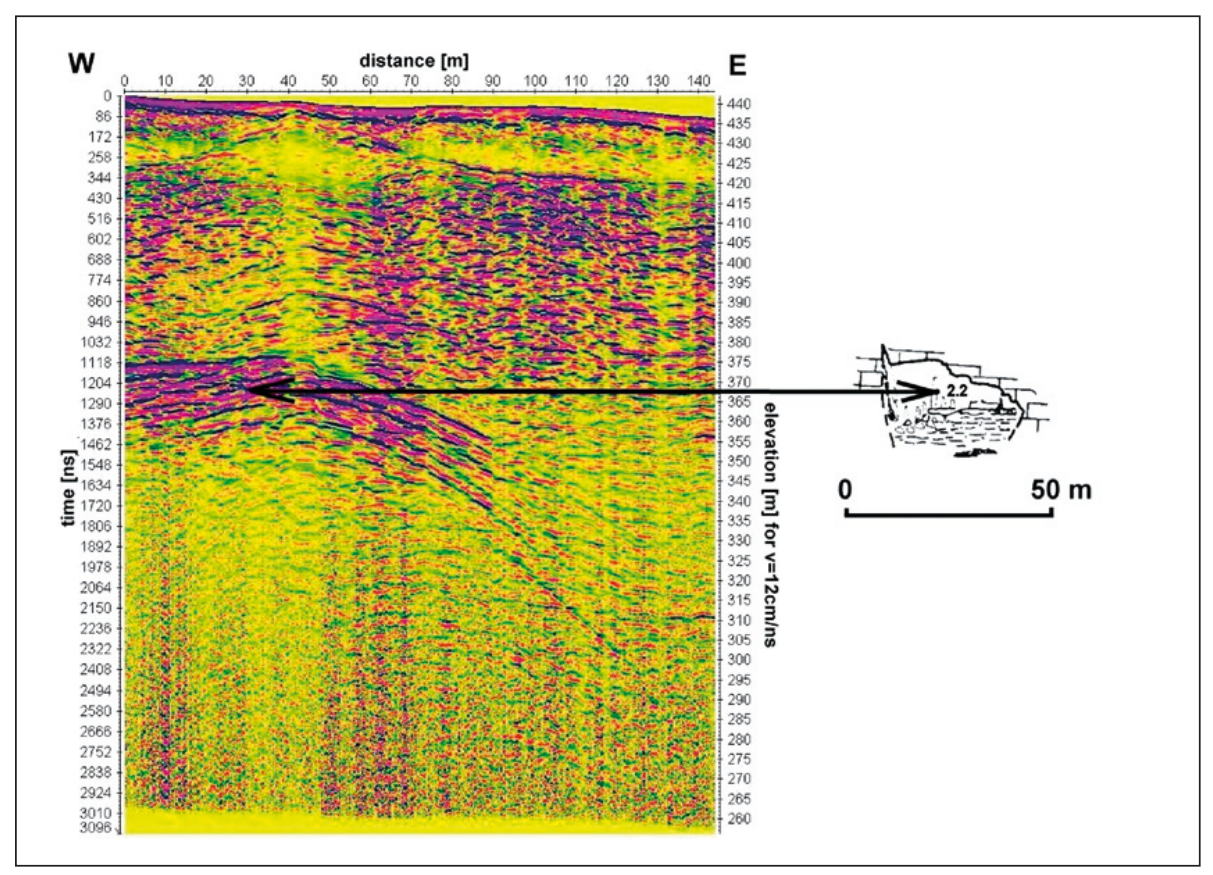

Fig. 7: GPR profile P10 and crosssection of Žibernova Dvorana by Gospodarič (1985). The arrow marks the corresponding trigonometric point.

depth of $26 \mathrm{~m}$ and at the end of the profile at the depth of $35 \mathrm{~m}$ (Fig. 6). Two other important cavities were found at a depth of $115 \mathrm{~m}$ and $125 \mathrm{~m}$ at positions between 65 and $90 \mathrm{~m}$ (Fig. 6). It should be the deeper cave level, which could be connected with Trhlovca, and was detected on profile P11 too.

The most important were two profiles P10 and P11, which were measured above the chamber Žibernova
Dvorana (Fig. 1). The big cavity at the depth of $65 \mathrm{~m}$ was clearly visible on the radarogram on the profile P10 with the ceiling from the beginning of the profile and end at the position of $50 \mathrm{~m}$ (Fig. 7). This is in perfect agreement with the diameter of this chamber and its depth (Fig. 3 in Gosar 2012). Above Žibernova Dvorana there are only two smaller cavities at depths of $35 \mathrm{~m}$ and $45 \mathrm{~m}$ below the surface at the position of $45-50 \mathrm{~m}$. 


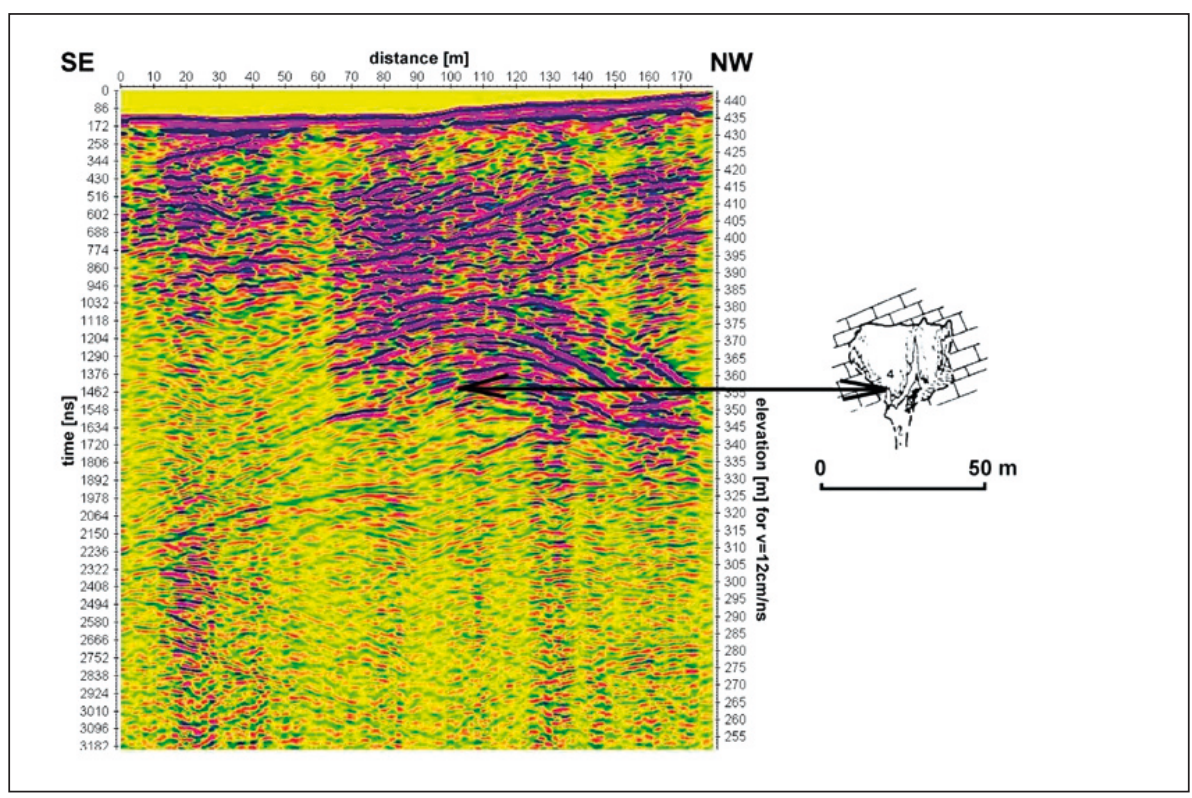

Fig. 8: GPR profile P11 and crosssection of Žibernova Dvorana by Gospodarič (1985). The arrow marks the corresponding trigonometric point.

A similar cavity as on profile P10 can be seen on profile P11 (Fig. 8). The ceiling of chamber Žibernova Dvorana starts at the position of $85 \mathrm{~m}$ and its top is at the position of $126 \mathrm{~m}$ at the depth of $65 \mathrm{~m}$. This is in good agreement with the cross-section of Žibernova Dvorana on the cave map. The bottom of the Žibernova Dvorana can be at the depth of $85 \mathrm{~m}$, i.e., $355 \mathrm{~m}$ above the sea. Another significant reflection can be seen at the position of $80 \mathrm{~m}$ and the depth of $110 \mathrm{~m}$. It looks like a corridor of deeper cave level, because almost at the same position it was detected on other profiles, especially south and west of cave Trhlovca.

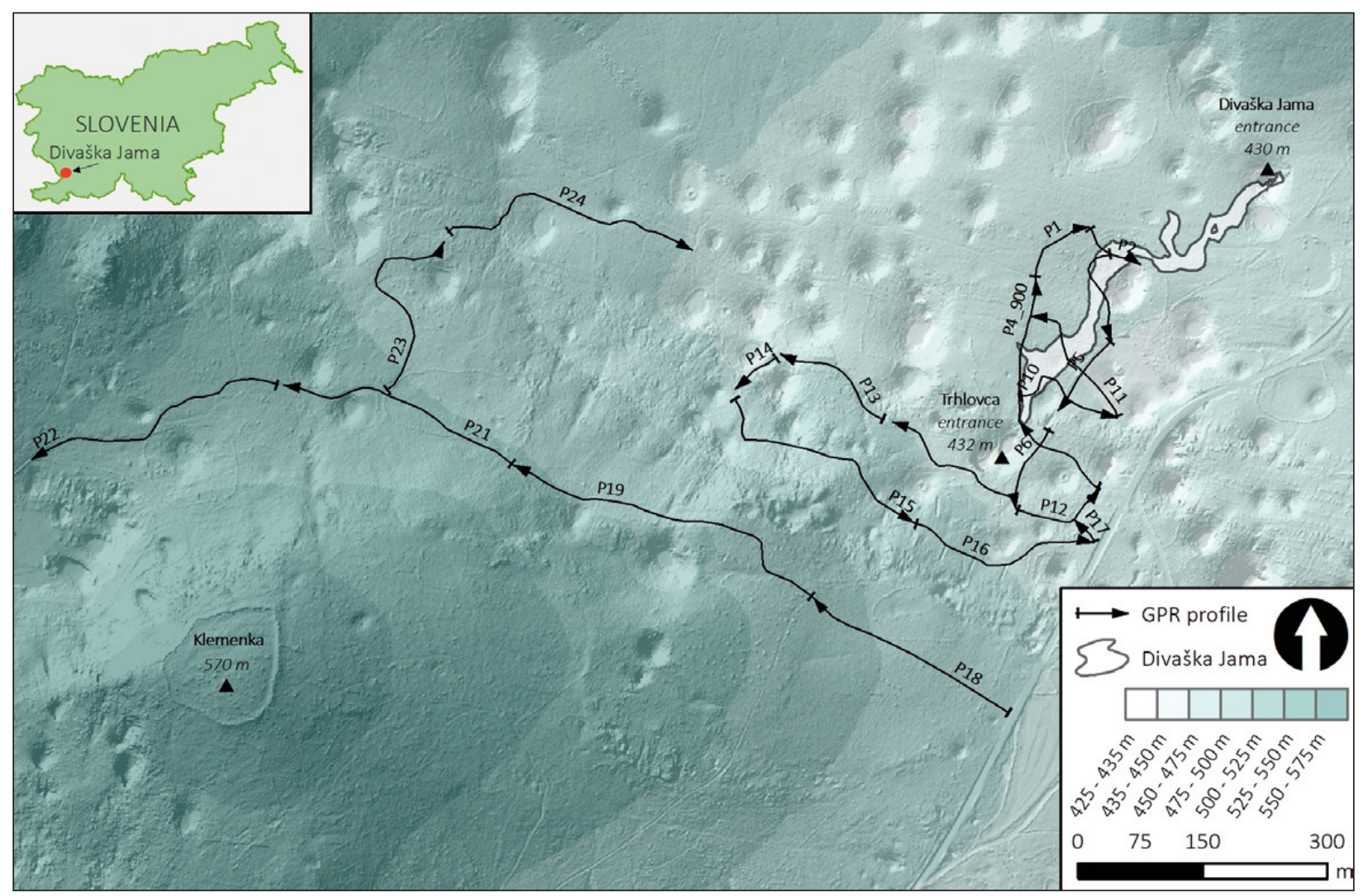

Fig. 9: Map of GPR profiles measured above Divaška Jama and in its surrounding. 


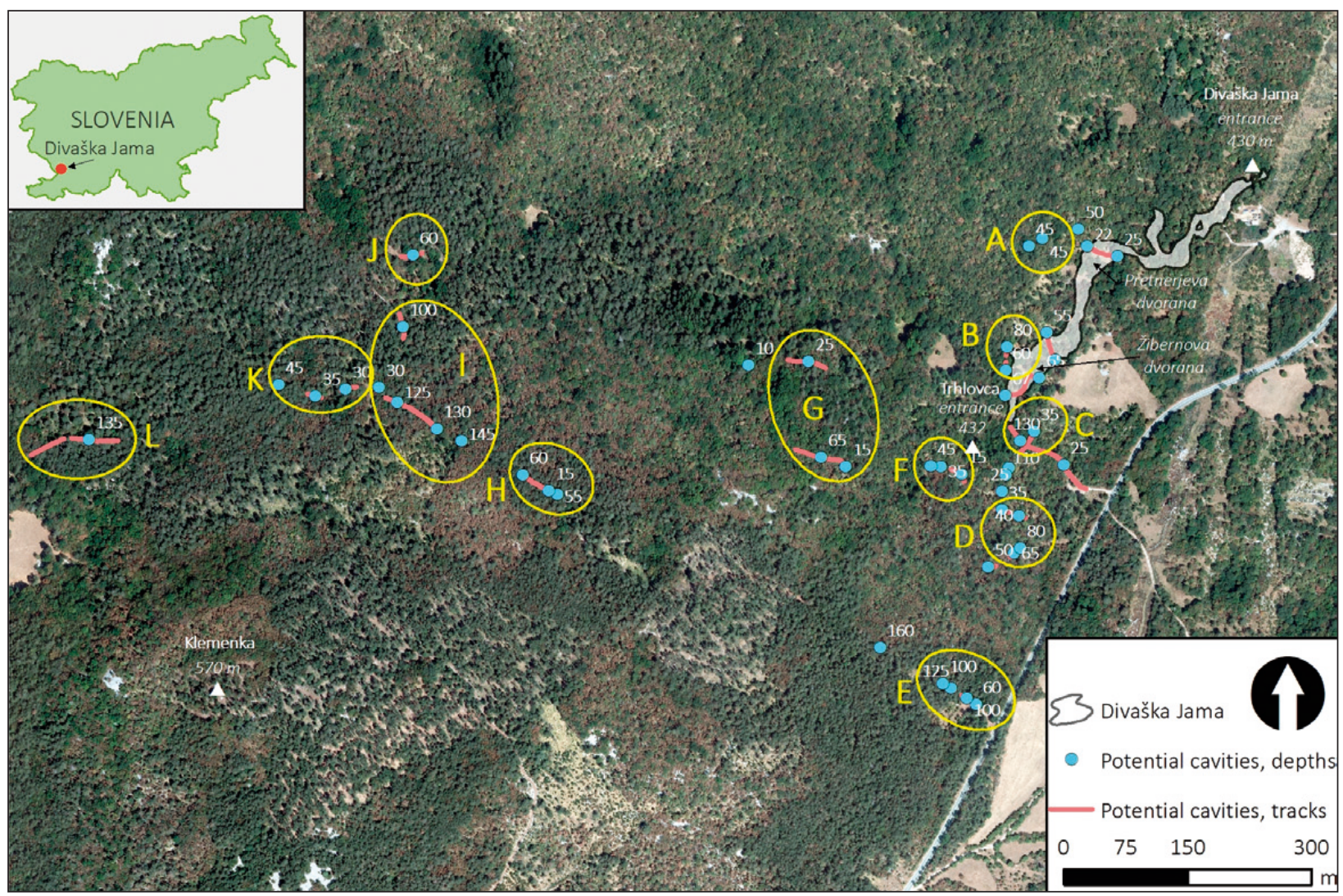

Fig. 10: Interpreted unknown large cavities detected by GPR. Numbers mark the depth; letters mark the cavities - see text and Tab. 2.

\begin{tabular}{|c|c|c|c|}
\hline Cavity & Depth & Lon & Depth \\
\hline A & $45.674613^{\circ}$ & $13.947492^{\circ}$ & $45 \mathrm{~m}$ \\
\hline B & $45.673198^{\circ}$ & $13.946906^{\circ}$ & $60 \mathrm{~m}$ \\
\hline C & $45.671975^{\circ}$ & $13.947049^{\circ}$ & $110 \mathrm{~m}$ \\
\hline D & $45.671108^{\circ}$ & $13.947064^{\circ}$ & $65 \mathrm{~m}$ \\
\hline E & $45.669801^{\circ}$ & $13.945870^{\circ}$ & $125 \mathrm{~m}$ \\
\hline F & $45.672064^{\circ}$ & $13.945886^{\circ}$ & $35 \mathrm{~m}$ \\
\hline G & $45.672121^{\circ}$ & $13.944032^{\circ}$ & $65 \mathrm{~m}$ \\
\hline H & $45.671800^{\circ}$ & $13.939920^{\circ}$ & $60 \mathrm{~m}$ \\
\hline I & $45.672735^{\circ}$ & $13.937636^{\circ}$ & $125 \mathrm{~m}$ \\
\hline J & $45.674315^{\circ}$ & $13.937689^{\circ}$ & $60 \mathrm{~m}$ \\
\hline K & $45.672760^{\circ}$ & $13.936240^{\circ}$ & $35 \mathrm{~m}$ \\
\hline L & $45.672274^{\circ}$ & $13.932838^{\circ}$ & $135 \mathrm{~m}$ \\
\hline
\end{tabular}

Tab. 2: The interpreted positions of centres of found cavities on GPR profiles measured behind cave Trhlovca. The depth was evaluated for the velocity $v_{m}=12 \mathrm{~cm} / \mathrm{ns}$ and the position is the nearest point of the cavity to the profile (without migration).

\section{MEASUREMENTS BEHIND TRHLOVCA CAVE TO THE SW}

On the course of two forest roads and one hunting footpath to the south and west of Trhlovca we measured 12 profiles (P12 - P24) of the length between 31 and $408 \mathrm{~m}$ (Fig. 9 and Tab. 1).

We found and interpreted cavities, which are marked on Fig. 10 and listed in Tab. 2.
The cavity A - NW from Pretnerjeva Dvorana.

The cavity A was found on the profile P1 (Fig. 3). A relatively large cavity ( $20 \mathrm{~m}$ wide) was found at several levels between $40 \mathrm{~m}$ and $60 \mathrm{~m}$ below the surface at the position of $45-70 \mathrm{~m}$. This depth corresponds to the bottom of Pretnerjeva Dvorana, which means that there should be inflow or outflow corridor to/from old active Divaška Jama. 


\section{The cavity B - NW from Žibernova Dvorana}

The similar large cavity was found on the profile P4_900 at the depth between 60 and $90 \mathrm{~m}$ below the surface at the position of $190-220 \mathrm{~m}$ (Fig. 2). Some relatively small parts of this cavity are free of sediments, indicated by strong reflections, but the total height of the cavity should be at least $20 \mathrm{~m}$ (the difference between reflection depths from the ceiling and the bottom). It should be part of Divaška Jama.

\section{The cavity $\mathrm{C}-\mathrm{S}$ of the known end of Divaška Jama}

Profile P6 crossed the large cavities at the depth of 110 $-130 \mathrm{~m}$ below the surface at the positions of $70-90 \mathrm{~m}$ (Fig. 6 - D6). Below the same profile P6 there are several cavities at the depth of the end of Divaška Jama or cave Trhlovca, i.e., 25 - 35 m (Fig. 6 - A6, B6 and C6). The same was found at the beginning of profile P4_900. It means that there are two cave levels and it is not clear, which of them was the main outflow from Divaška Jama at the time of active flow through it.

\section{The cavities D - S of the known end of Divaška Jama}

Large cavities (D) were found at the depths of $40-80 \mathrm{~m}$ on profile P16 at position of $90-200 \mathrm{~m}$ (Fig. 11). The width of these cavities is between 20 and $40 \mathrm{~m}$, which correspond to the diameters and position of Divaška Jama. We suppose that these cavities represent an unknown extension of Divaška Jama and the main corridors went through the cavity F, which is near Trhlovca (see next paragraph).

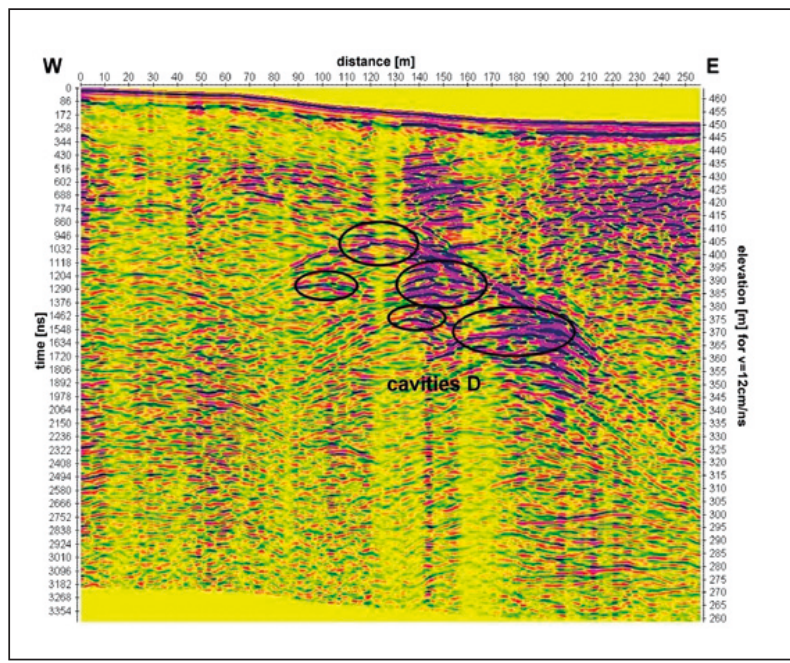

Fig. 11: GPR profile P16.

The cavities $\mathrm{E}$ - $\mathrm{S}$ of the known end of Divaška Jama The most southern profile P18 detected between positions of 30 and 150 several cavities (most of them with air, which is detectable by the sequence blue-red-blue

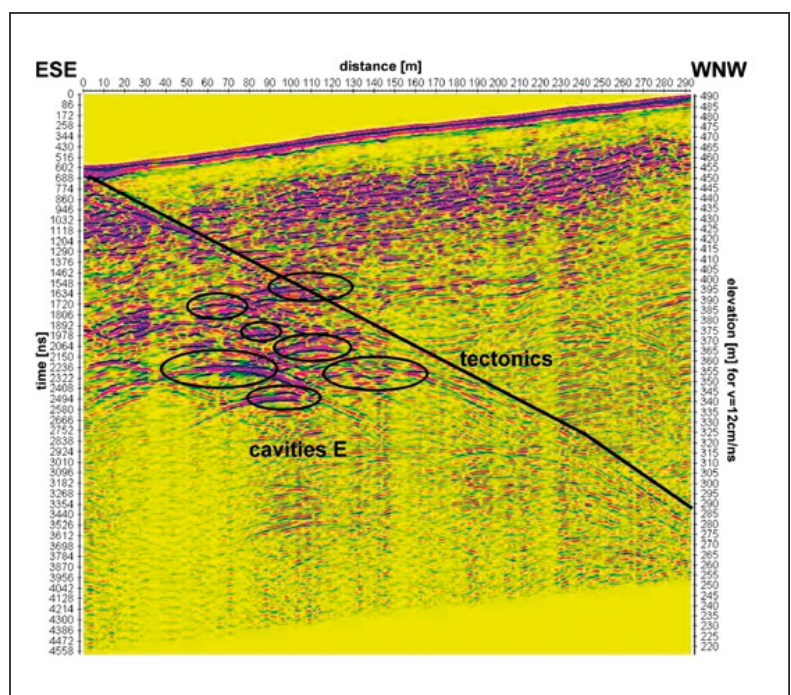

Fig. 12: GPR profile P18.

on radarograms as the wave is travelling from limestone to air, than to sediments and back to limestone) at the depths of $60-110 \mathrm{~m}$. All of them are tied to the presumed fault zone (see Fig. 23), which divides the massif into two different parts. The eastern part (left on Fig. 12) is full of caves and cavities and the western part (right on Fig. 12) is practically without karst phenomena. We think that these cavities are part of Divaška Jama because of the same depth and diameters.

\section{The cavities F - above the Trhlovca cave}

Several cavities F were found at the profile P12 at depths from $15 \mathrm{~m}$ to $60 \mathrm{~m}$. The profile P12 passed above Trhlov$\mathrm{ca}$ at the position of $160-210 \mathrm{~m}$ (Fig. 13). Many of detected cavities are known at the depth of $40 \mathrm{~m}$, but the caves deeper than $60 \mathrm{~m}$ below the surface are not known yet. The cavity at the depth of $40-50 \mathrm{~m}$ at the position of $70-105 \mathrm{~m}$ belongs to group D. It should be a part of Divaška Jama.

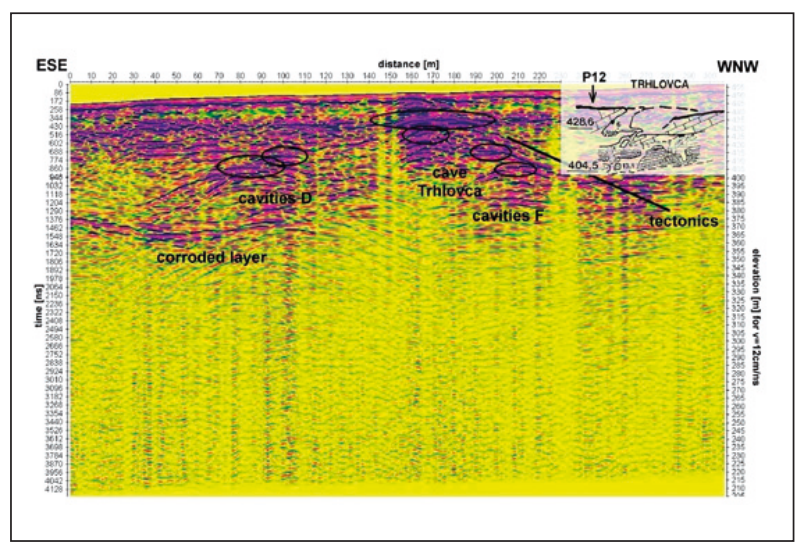

Fig. 13: GPR profile P12 and cross-section of cave Trhlovca by Gospodarič (1985). 


\section{The cavities G - W of the Trhlovca cave}

Both profiles P13 and P15 (Figs. 14 and 15) show an important cavity of large length. It looks like corroded interlayer surface or an overthrust. The slope of this surface is to the south parallel to the layers in the surroundings. This surface continues to the profile P12, where is at the depth of $15 \mathrm{~m}$ and is clearly visible in the entrance

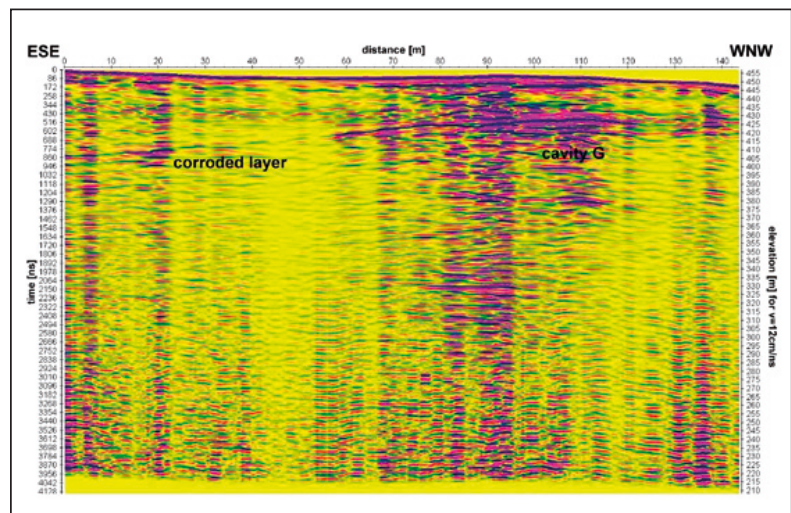

Fig. 14: GPR profile P13.

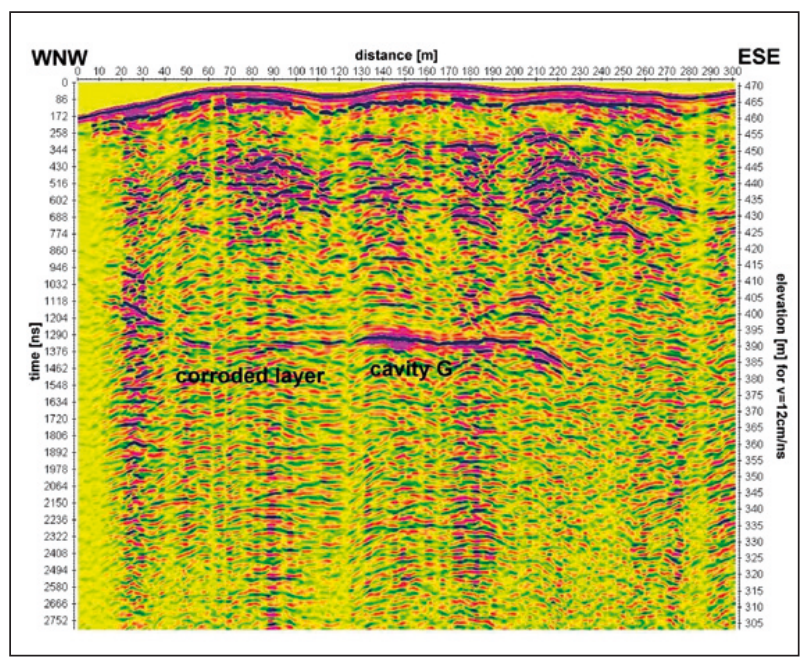

Fig. 15: GPR profile P15

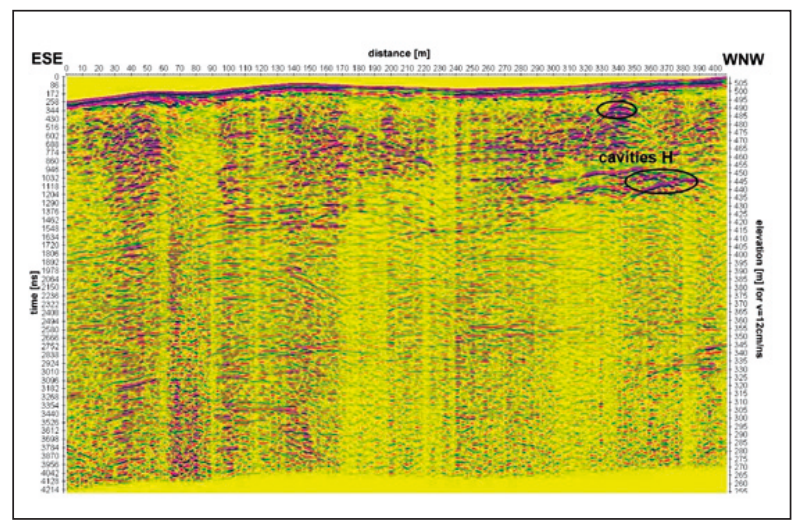

Fig. 16: GPR profile P19 of Trhlovca (the whole upper cave is based on this structural geological layer or thrust fault).

\section{The cavities $\mathrm{H}$}

On the profile P19 there are several important cavities only around the position of $340 \mathrm{~m}$ at the depths of $15 \mathrm{~m}, 50 \mathrm{~m}$ and $60 \mathrm{~m}$ (Fig. 16). They are at the depth of $55-60 \mathrm{~m}$ (445

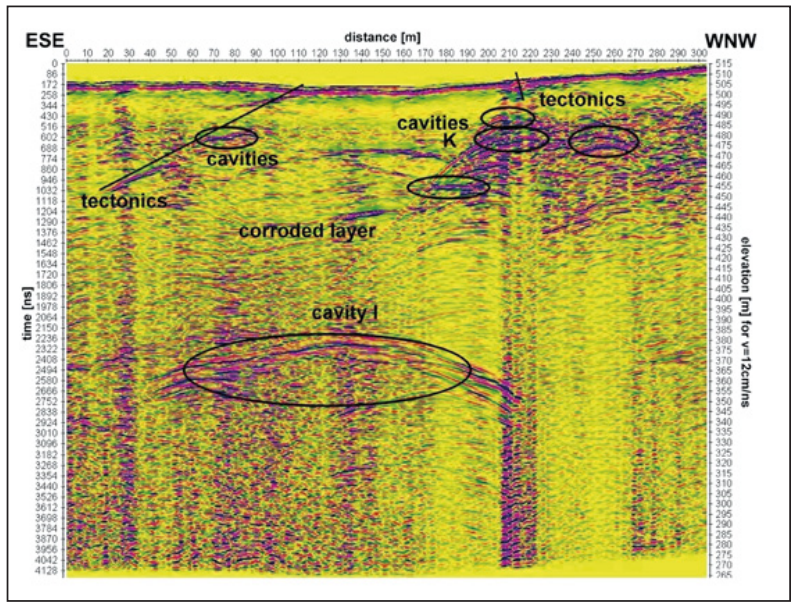

Fig. 17: GPR profile P21.

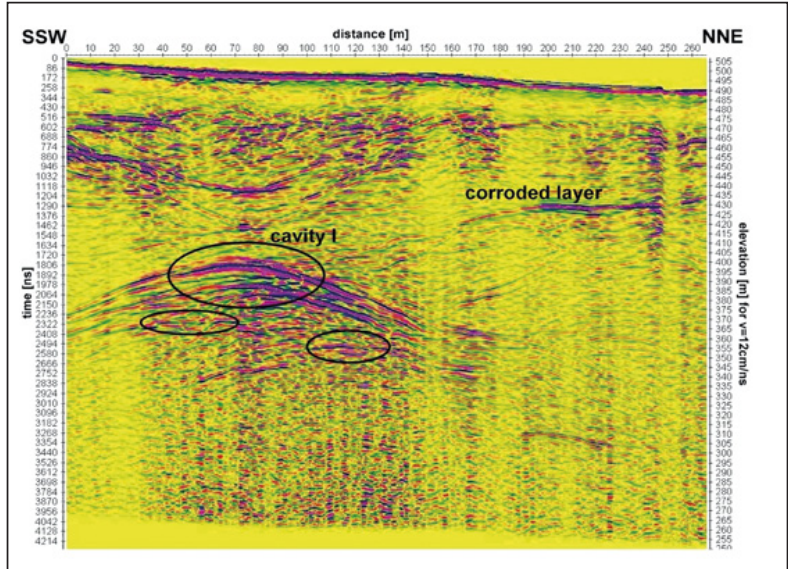

Fig. 18: GPR profile P23.

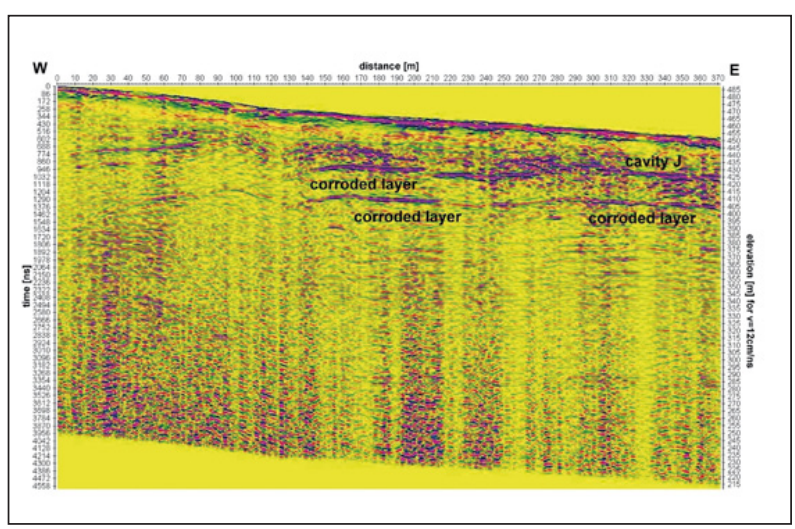

Fig. 19: GPR profile P24. 
- $450 \mathrm{~m}$ a.s.l.), which is at the same position as the upper cave level in Trhlovca and the surface above Divaška Jama. These caves should not be connected to Divaška Jama.

\section{The cavity I}

The largest cavity I at the position of Divaška Jama (370 $420 \mathrm{~m}$ a.s.l.) was found at the depth of $140 \mathrm{~m}$ (360 - 375 $\mathrm{m}$ a.s.l.) on profile P21 (Fig. 17). The length of the ceiling is approximately $90 \mathrm{~m}$ (between positions $60 \mathrm{~m}$ and $150 \mathrm{~m}$ ). Both ends of the cavity I are marked by strong hyperbolas in the same way as on the profiles $\mathrm{P} 2$ or P10 for example. There are many other cavities or caves at the positions between $160-270 \mathrm{~m}$ at the depth of $20-55 \mathrm{~m}$. They are connected with the fault zone, which is visible on the surface at the position of $215 \mathrm{~m}$.

The other large karst object at the level of Divaška Jama was found on the profile P23 at the depth of 95 $120 \mathrm{~m}$ below the surface (Fig. 18). It confirms that there is another large corridor besides Divaška Jama at the same level. This corridor was crossed by profiles P21 and P23.

\section{The cavity J}

The cavity J was developed on the interlayer geological structure or thrust fault at the end of profile P23 at the depth of $60 \mathrm{~m}$ (Fig. 18) and is visible on the profile P24 too (Fig. 19). Probably it is the same structural geological element, which was detected on profiles P12, P13 and P15 (Figs. 13, 14 and 15). This structural geological element must be extraordinarily susceptible to corrosion.

\section{The cavity $\mathrm{K}$}

Many other cavities were detected at the end of the profile P21 (between positions $200 \mathrm{~m}$ and $260 \mathrm{~m}$ ) at the depth of $15-40 \mathrm{~m}$ around the large tectonic zone of the $10 \mathrm{~m}$ width, which was found at the position of $210-220 \mathrm{~m}$ (Fig. 17). This zone is filled with sediments, especially to the depth of $10 \mathrm{~m}$, which does not allow the radar signal to penetrate large depths (more than $60 \mathrm{~m}$ ).

\section{The cavity $L$}

The last big karst object - cavity - was found at the end of profile P22 (position $230-280 \mathrm{~m}$ ) at the depth of $130-150$ m (Fig. 20 - cavity L). Because located at the end of the surveyed area, the orientation of this huge corridor is not known. The level is the same as for Divaška Jama, i.e.,s 365 - 390 m a.s.l. and the width of cavity (and reflection amplitude) is similar (several dozen of meters).

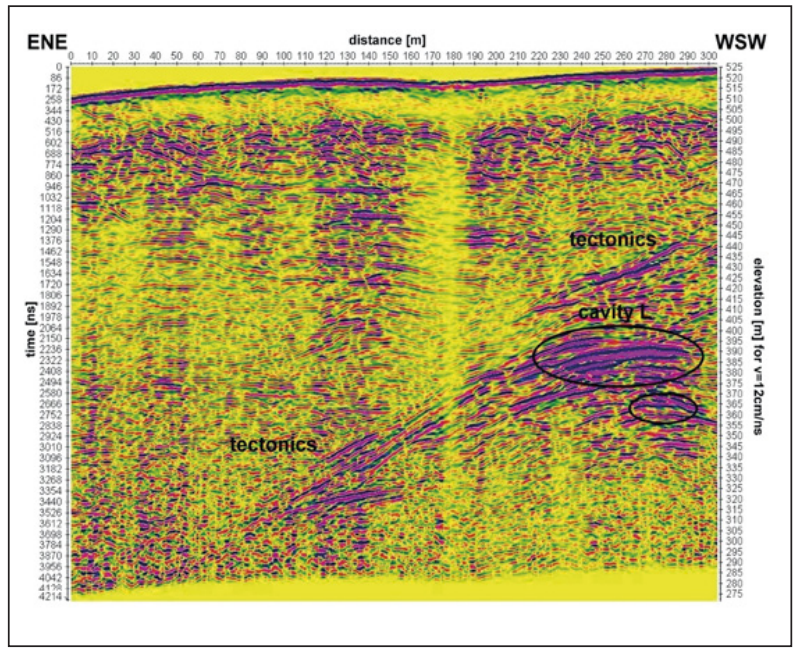

Fig. 20: GPR profile P22.

\section{DISCUSSIONS}

\section{PENETRATION DEPTH}

The penetration depth depends mostly on the properties of the rocks and, especially, the sedimentary cover, which consists mainly of clay minerals with water, which has high permittivity and high conductivity. In the karst areas, the sedimentary cover is usually very thin and limestone has low conductivity and permittivity, which is advantageous for radar measurements. However, the common GPRs have the penetration depth less than $30 \mathrm{~m}$, even when low frequencies and large antennas are used. Smith \& Jol (1995) experimentally estimated that the penetration depth for $25 \mathrm{MHz}$ antenna and Quaternary sedimentary environment (above the level of mineralized water) is between 52 and 57 meters. For $100 \mathrm{MHz}$ antenna the penetration depth was reduced to $37 \mathrm{~m}$. The results of experimental measurements above Divaška Jama (Gosar 2012) confirmed previous estimations. The problem is in the maximum power output at common GPRs, which does not reach 1MW because semiconductors do not allow switching big currents and short pulses. The "Roteg" GPR uses spark gaps instead of semiconductors, which allow producing pulses of the length of 3-4 ns with the maximal voltage on antenna $20 \mathrm{kV}$. The power output reaches up to $20 \mathrm{MW}$ in the pulse regime.

During the measurement in the Divaška Jama area we used 3-m antennas with central frequency of $50 \mathrm{MHz}$ and we clearly detected the reflections from the depth of $200 \mathrm{~m}$ after data processing (filtering, stacking and aver- 


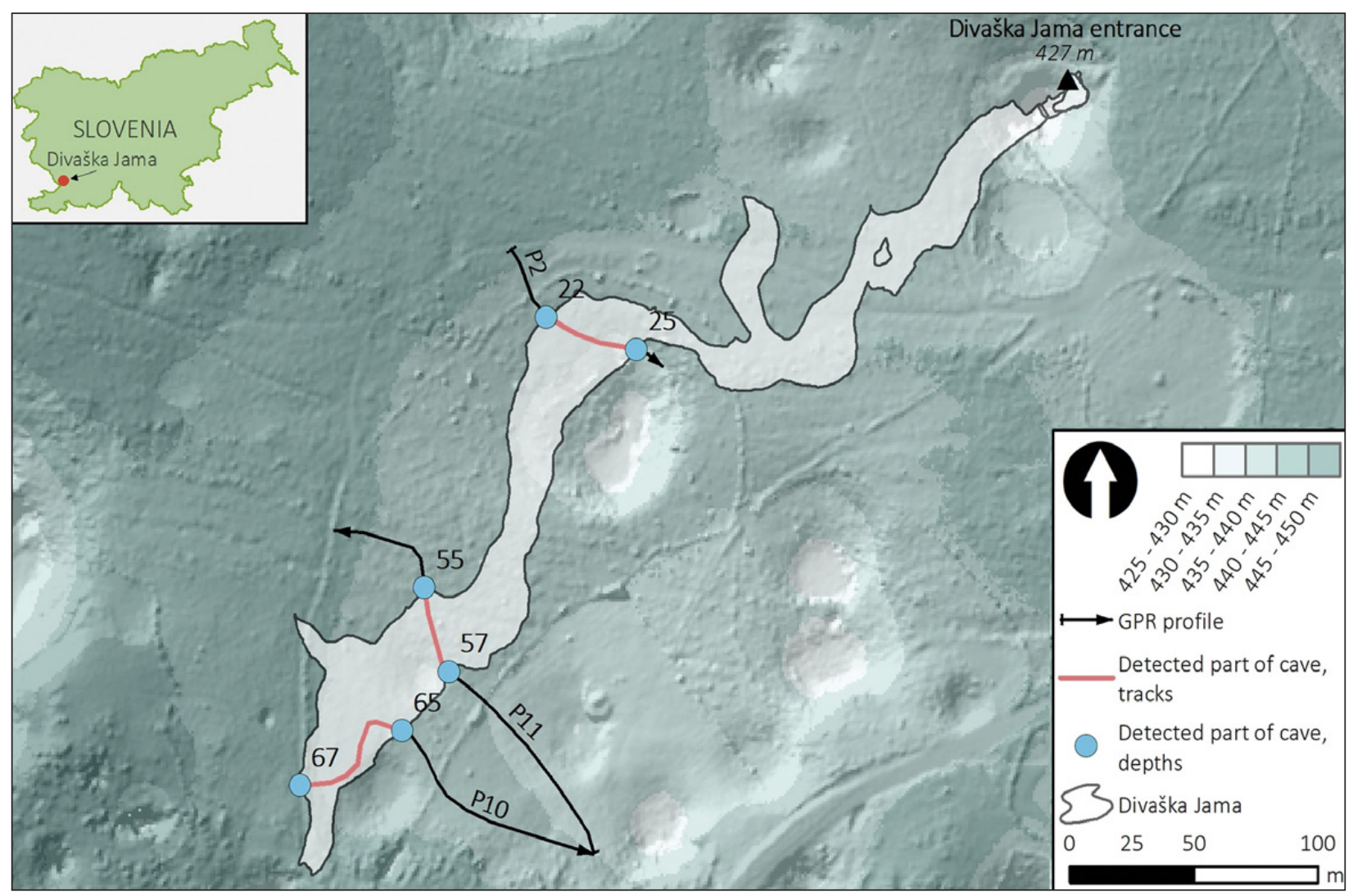

Fig. 21: Contour map of Divaška Jama and detected cavities with the depth.

aging in both $\mathrm{x}$ and $\mathrm{y}$ axes) (see for example Figs. 20 and 11). The ceiling of Divaška Jama at the depths of $40-60$ $\mathrm{m}$ was detectable right in the field after stacking several samples only (Figs. 4, 7 and 8).

\section{HORIZONTAL AND VERTICAL RESOLUTIONS}

The theoretical vertical and horizontal resolutions depend mainly on the length (width) of the pulse and the velocity of EM waves in the rocks. The vertical (range) resolution is not a problem, because, according to Annan (2009), the range resolution $r$ is

$$
r=v_{m} \times \frac{W}{4}
$$

where $v_{m}$ - velocity of the wave propagation through the material and $W$ is pulse width. The velocity depends only on the permittivity of the material. In our case we used the velocity $v_{m}$ for wet limestone $12 \mathrm{~cm} / \mathrm{ns}$ (Cassidy 2009). For $50 \mathrm{MHz}$ antenna and limestone $r$ should be less than $1 \mathrm{~m}$, which allows detecting the typical caves in the area.

The theoretical horizontal (lateral) resolution $\boldsymbol{L}$ between two in-homogeneities depends on the length of the pulse and the velocity of EM waves in rocks according to the equation (Annan 2009)

$$
L=\sqrt{v_{m} \times W \times \frac{d}{2}}
$$

where $d$ is the depth (distance from the GPR). For 50 $\mathrm{MHz}$ antenna, limestone and the depth of $100 \mathrm{~m}, L$ should be less than $11 \mathrm{~m}$. For the depth of $50 \mathrm{~m}, L$ should be less than $8 \mathrm{~m}$. If we use instead of the wavelength the width of pulse, which is for "Roteg" GPR 3 - 4 ns, the lateral resolution will be $4.25 \mathrm{~m}$ only at the depth of 100 $\mathrm{m}$. We can compare the theoretical lateral resolution with the observations of the diameter of the chamber ceilings of Divaška Jama. We measured three profiles above Pretnerjeva Dvorana and Žibernova Dvorana. The first and last deviations of the hyperbola course at the ends of the "flat" part of the reflection mark the beginning and end of the ceiling.

The "beginning" of the cave on the profile $\mathrm{P} 2$ is at the position of $33 \mathrm{~m}$ at the depth of $22 \mathrm{~m}$ (Fig. 4). The "end" of cave can be assumed at the position of $84 \mathrm{~m}$ at the depth of $25 \mathrm{~m}$. When we compare these points with 


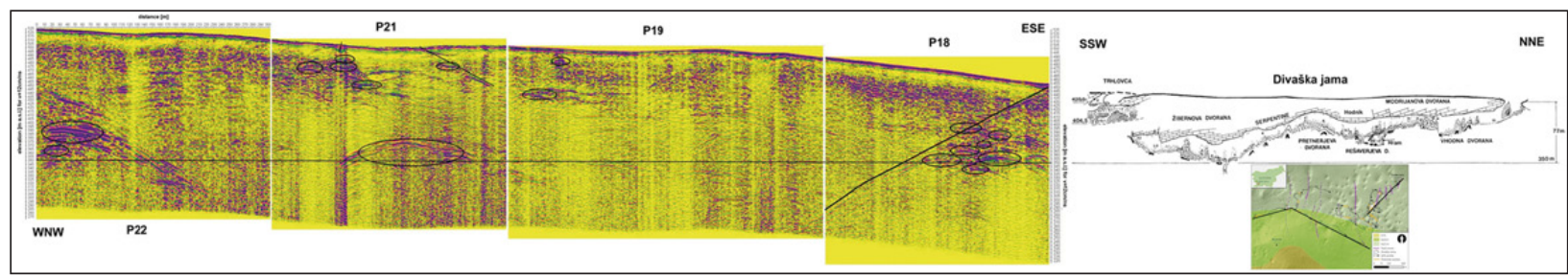

Fig. 22: The mosaic of radarograms of profiles P18 - P22 and the cross-section of Divaška Jama (according to Gospodarič 1985).

the contours of Divaška Jama (Figs. 1, 10 or 21), we can see that lateral error is less than $5 \mathrm{~m}$.

The "beginning" of the cave on the profile P10 is outside the radarogram at the depth of (approximately) $67 \mathrm{~m}$ (Fig. 7). The "end" of cave can be assumed at the position of $54 \mathrm{~m}$ at the depth of $65 \mathrm{~m}$. When we compare this point with the contours of the Divaška Jama (Figs. 1,10 or 21 ), we can see that lateral error is less than $5 \mathrm{~m}$.

The "beginning" of the cave on the profile P11 is at the position of $85 \mathrm{~m}$ at the depth of (approximately) 57 $\mathrm{m}$ (Fig. 8). The "end" of cave can be assumed at the position of $124 \mathrm{~m}$ at the depth of $55 \mathrm{~m}$. When we compare this point with the contours of the Divaška Jama (Figs. 1,10 or 21 ), we can see that lateral error is again less than $5 \mathrm{~m}$.
We can compare the GPR method with other geophysical or geological methods:

a) integral methods like Very low frequency method (VLF), Resistivity method (RM), Vertical electrical sounding (VES) or Electrical profiling (EP) are relatively easy, but their penetration depth is less than one half of the electrode separation and the vertical and lateral resolutions are relatively low as we suppose the really square errors $\mathrm{E} \sim 15 \%$ depending on the electrode separation and resistivity contrast (Mariita 1986).

b) differential or point methods like Seismic reflection (SR) or drilling are very precise to the depths of several hundred metres, but they are very expensive (more than several thousand times) in comparison with GPR method.

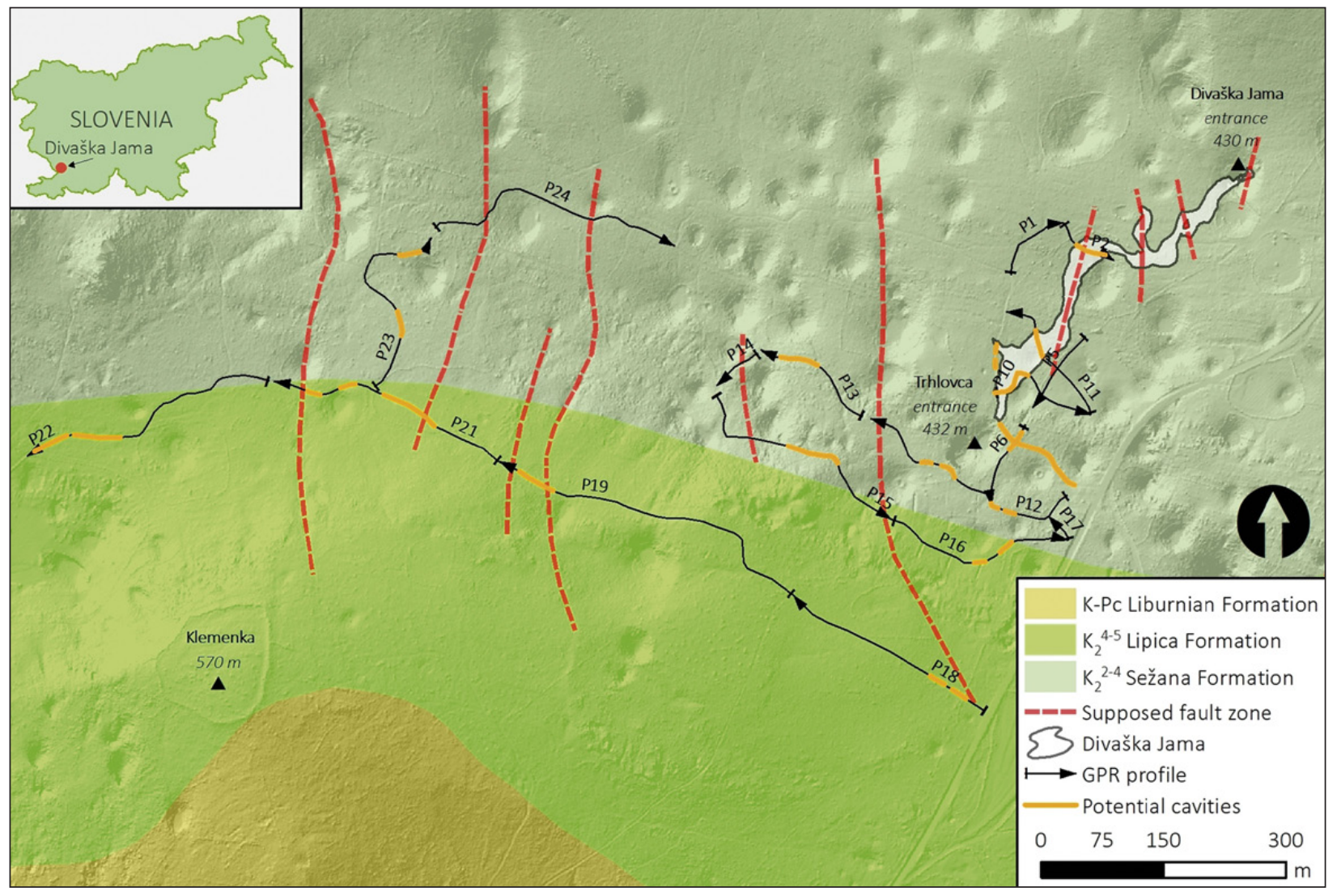

Fig. 23: Lidar map (source ARSO 2017) with GPR "Roteg" profiles (black), tectonics (violet), layers (green and grey) and detected large cavities (orange). Geology after Jurkovšek et al. 1996. 
The main limitation factor of using GPR is the penetration depth, which for common kinds of GPRs in common conditions (crystalline rocks and soil cover) reaches only several metres (Bláha et al. 1999). Because the new kind of GPR - GPR "Roteg" - has more than 100 times bigger power output and the high sensitivity for low frequencies, especially using 6-m long antennas, the penetration depth is much bigger than for common kinds of GPRs. The positive tested penetration depth of Roteg GPR in the suitable conditions like limestone with small or no cover is much bigger than several hundred metres.

\section{CAVE LEVEL(S)}

When we compare the elevations of all recognised caves on the long profile, composed of several radarograms, measured from the road Divača - Lokev to the end of profile P22 W of the Klemenka hill (Fig. 22 or 23) with the vertical cross-section of Divaška Jama, we can see that all big cavities, which were detected below profiles P18, P21 and P22 are almost at the same level of 350 - $400 \mathrm{~m}$ a.s.l. (Fig. 22). There is also another group of cavities at the level of $420-450 \mathrm{~m}$ a.s.l., which corre- sponds to Trhlovca. Both groups are separated by the gap which extends in the vertical direction, and is visible almost everywhere and probably presents tectonic zone (Fig. 22).

\section{TECTONICS}

The main fault and fault zones were recognisable not only on the Lidar map by the surface morphology and structural discontinuities, but many of them were clearly visible on radarograms. The good example of the fault zone is on profile $\mathrm{P} 1$ at the position of $77 \mathrm{~m}$ (Fig. 3). One of the best expressed faults was detected by three profiles - P18 at the position of $0 \mathrm{~m}$, on profile $\mathrm{P} 15$ at the position of $280 \mathrm{~m}$ (Fig. 15) and on profile P12 at the position of 300 $\mathrm{m}$. The other important fault zone is clearly visible on the profile P12 at the position of the cave Trhlovca (Fig. 13). Two big faults are visible on profile P21 at the positions $110 \mathrm{~m}$ and $212 \mathrm{~m}$ (Fig. 17).

Evaluation of the tectonic pattern of the measured area (Fig. 23) showed that courses of the caves follow the prevailing tectonics and fault system pattern not only in Divaška Jama, but everywhere in the study area.

\section{CONCLUSION}

At first we tested the penetration depth of novel GPR system above known parts of Divaška Jama and found that ceilings of big chambers are clearly detectable at depths of more than $60 \mathrm{~m}$ below the surface.

During the next measurements south and west from Trhlovca cave on an area approximately $1000 \times 300 \mathrm{~m}$ we found the possible continuation of the Divaška Jama and other large caves at the same level (approximately 360 $410 \mathrm{~m}$ a.s.l.).

The penetration depth of the GPR "Roteg" was sure- ly more than $200 \mathrm{~m}$ using 3-m antennas, $50 \mathrm{MHz}$ frequency and maximal voltage output of $20 \mathrm{kV}$ on transmitting antenna.

We prepared a geological sketch based on Lidar map (ARSO 2017) and we estimated possible tectonic zones, which are close to recognised large cavities and caves at the Divaška Jama level (Fig. 23).

By the use of GPR "Roteg" on karst surface we were able to detect known caves, new unknown caves and tectonic zones up to $200 \mathrm{~m}$ under surface.

\section{ACKNOWLEDGEMENTS}

Study was financially supported by „Karst Research Programme" (P6-0119), EPOS IP project (ZRC SAZU), Ing. Rudolf Tengler - RTG and CoalExp Pražmo. We are greatful to Dr. Trevor Shaw for English text improvement. 


\section{REFERENCES}

Allred, B.J., Daniels, J.J. \& M.R. Ehsani, 2008: Handbook of Agricultural Geophysics.- CRC Press, pp. 410, Boca Raton.

Annan, A.P., 2009: Electromagnetic Principles of Ground Penetrating Radar.- In: Jol, H.M. (ed.) Ground Penetrating Radar: Theory and Applications. Elsevier, pp. 3-40, Amsterdam. DOI: https://doi.org/10.1016/ B978-0-444-53348-7.00001-6.

ARSO, 2017: Lidar data fishnet.- [Online] Available from: http://gis.arso.gov.si/ [Accessed 28th August 2017].

Bláha, P., Karous, M., Kněz, J. \& K. Müller, 1999: Možnosti georadaru v inženýrském průzkumu (Ground penetreting radar and its ability in engineering investigation).- Geotechnika, 3/99, 12-15.

Cassidy, N.J., 2009: Electrical and Magnetic Properties of Rocks, Soils and Fluids.- In: Jol, H.M. (ed.) Ground Penetrating Radar: Theory and Applications. Elsevier, pp. 41-72, Amsterdam. DOI: https://doi. org/10.1016/B978-0-444-53348-7.00002-8.

Chamberlain, A.T., Sellers, W., Proctor, C. \& R. Coard, 2000: Cave detection in limestone using Ground Penetrating Radar.- Journal of Archaeological Science, 27, 10, 957-964. DOI: https://doi.org/10.1006/ jasc. 1999.0525 .

Gosar, A., 2012: Analysis of the capabilities of low frequency ground penetrating radar for cavities detection in rough terrain conditions: The case of Divača cave, Slovenia.- Acta Carsologica, 41, 1, 77-88. DOI: https://doi.org/10.3986/ac.v41i1.49.

Gospodarič, R., 1985: On the speleogenesis of Divaška jama and Trhlovca Cave. - Acta Carsologica, 23, 5-32.

Hladík, V. \& J. Hruška, 1999: Jak hluboko s georadarem?.- Geotechnika, 4/99, 10-11.

Jurkovšek, B., Toman, M., Ogorelec, B., Šribar, L., Drobne, K., Poljak, M. \& L. Šribar, 1996: Geological Map of the Southern Part of the Trieste-Komen Plateau, Cretaceous and Paleogene Carbonate Rocks, 1:50.000.Inštitut za geologijo, geotehniko in geofiziko, pp. 143, Ljubljana.

Kalenda, P., Tengler, R., Doležal, F.K., Reichel, V. \& L. Chlup, 2016: Geofyzikální týden 2015.- Speleo, 68, $15-23$.
Kalenda, P. \& R. Tengler, 2016: Porovnání výsledků geofyzikálních metod nad Holštejnskou jeskyní.- Speleofórum 2016, 35, 31-34.

Kalenda, P., Tengler, R., Cendelín, R., Slezák, L. \& J. Pokorný, 2017a: Georadarová měření nad Pekárnou 2016.- Speleofórum 2017, 36, 30-35.

Kalenda, P., Tengler, R., Blatnik, M. \& F. Drole, 2017b: Georadarová měření Postojna 2016.- Speleofórum 2017, 36, 87-89.

Kalenda, P., Tengler, R., Šebela, S., Blatnik, M. \& F. Drole, 2018: Field test of the ground penetrating radar (GPR) above karst of Planina cave (Slovenia) for $>150$ m depth.- Acta Carsologica, Submitted.

Knez, M. \& T. Slabe, 2005: Non-destructive georadar researches in the area of road subsidence of motorway near Postojna, classical Karst, Slovenia.- Geophysical Research Abstracts, 7.

Mariita, N.O., 1986: Schlumberger vertical soundings: Techniques and interpretations with examples from Krísuvík and Glerardarur, Iceland and Olkaria, Kenya.- [Online] Available from: https://orkustofnun.is/gogn/unu-gtp-report/UNU-GTP-1986-05. pdf [Accessed 4th March 2017].

Pavlič, M.U. \& B. Praznik, 2011: Detecting karstic zones during highway construction using ground-penetrating radar.- Acta Geotech. Slovenica, 8, 1, 17-27.

RTG-Tengler, 2013: [Online] Available from: http://georadar.rtg-tengler.cz [Accessed 4th June 2017].

Smith, D.G. \& H.M. Jol, 1995: Ground penetrating radar: antenna frequencies and maximum probable depths of penetration in Quaternary sediments.- Journal of Applied Geophysics, 33, 1-3, 93-100. DOI: https:// doi.org/10.1016/0926-9851(95)90032-2.

Tengler, R., Kalenda, P., Doležal, F.K. \& L. Chlup, 2016: Testování nového typu georadaru s velkým hloubkovým dosahem.- Speleofórum 2016, 35, 35-42.

van der Kruk, J., Slob, E.C. \& J.T. Fokkema, 1999: Background of ground-penetrating radar measurements.- Geologie en Mijnbouw, 77, 177-188. 